\title{
Sexual Dimorphism of the Pronotum in Dorcadion micans J. Thomson, 1867 (Coleoptera: Cerambycidae) Using Geometric Morphometrics
}

\author{
Atılay Yağmur OKUTANER Aslı DOĞAN SARIKAYA* \\ Kirşehir Ahi Evran University, Faculty of Art and Science, Department of Anthropology, Kirşehir, Turkey.
}

How to cite: Okutaner, A.Y. \& Doğan Sarikaya, A. (2021). Sexual Dimorphism of the Pronotum in Dorcadion micans J. Thomson, 1867 (Coleoptera: Cerambycidae) Using Geometric Morphometrics. J. Anatolian Env. and Anim. Sciences, 6(1), 88-91.

Atıf yapmak için: Okutaner, A.Y. \& Doğan Sarikaya, A. (2021). Dorcadion micans J. Thomson, 1867 (Coleoptera: Cerambycidae) Pronotumunda Geometrik Morfometri Kullanarak Eşeysel Dimorfizm. Anadolu Çev. ve Hay. Dergisi, 6(1), 88-91.

(iD): https://orcid.org/0000-0002-8739-0122 (iD: https://orcid.org/0000-0001-6585-1824

*Corresponding author's: Aslı DOGAN SARIKAYA

Kırșehir Ahi Evran University, Faculty of Art and Science, Department of Anthropology,

40100, Kırşehir, Turkey.

凶: aslidgn@gmail.com

\begin{abstract}
Sexual dimorphism is one of the most notable sources of phenotypic variation in animals. The expression of sexual traits varies widely for many species of insects. In this study, we analyzed the sexual size and shape dimorphism of pronotum in Turkish endemic species, Dorcadion micans J. Thomson, 1867 (Coleoptera: Cerambycidae). Our results showed that there are a statistically significant sexual size and shape dimorphism in pronotum. Males have a smaller pronotum size than females, and the pronotum shape of males is longer and sharper than female. Multivariate regression results indicated that size has a negligible influence on the differentiation in pronotum shape between sexes.
\end{abstract}

Keywords: Coleoptera, Dorcadion micans, geometric morphometrics, sexual dimorphism, shape variation.

\section{Dorcadion micans J. Thomson, 1867 (Coleoptera: Cerambycidae) Pronotumunda Geometrik Morfometri Kullanarak Eşeysel Dimorfizm}

*Sorumlu yazar:

Aslı DOĞAN SARIKAYA

Kırsehir Ahi Evran Üniversitesi, Fen

Edebiyat Fakültesi, Antropoloji Bölümü,

Kırşehir, Türkiye.

凶: aslidgn@gmail.com
Öz: Eşeysel dimorfizm, hayvanlarda fenotipik varyasyonun en önemli kaynaklarından biridir. Birçok türdeki böcekler için eşeysel özelliklerin ifadesi büyük farklılıklar gösterir. Bu çalışmada, Türkiye'de endemik tür olan Dorcadion micans J. Thomson, 1867 (Coleoptera: Cerambycidae) 'da pronotumun eşeysel büyüklük ve şekil dimorfizmini analiz ettik. Sonuçlarımız, pronotumda istatistiksel olarak eșeysel büyüklük ve şekil dimorfizmini göstermiștir. Erkekler dişilerden daha küçük pronotum boyutuna sahiptir ve erkeklerin pronotum şekli dişilerinkinden daha uzun ve daha keskindir. Çok değişkenli regresyon sonuçları, büyüklüğün cinsiyetler arasında pronotum şeklindeki farklılaşma üzerinde göz ardı edilebilir bir etkiye sahip olduğunu göstermiştir.

Anahtar kelimeler: Coleoptera, Dorcadion micans, eșeysel dimorfizm, geometrik morfometri, sekil varyasyonu.

\section{INTRODUCTION}

Because of their biological characteristics such as slow mobility and flightless, members of the Dorcadion may divided into isolated populations. The quantitative and qualitative observations carried out on these isolated populations can provide important information about the evolution of the genus. (Baur et al., 2002; Baur et al., 2005; Doğan Sarıkaya et al. 2019). Morphological characters usually employ for revealing differences between sexes. Entomologists pay attention to sexual dimorphism in many studies since the differences between sexes are not clear or the individuals are very small. Thus, finding distinctive external morphological characters is important in separating the sexes. Thus, to find a discriminative character allow easy determination of sexes (Benitez, 2013). Sexual size dimorphism is one of the most important factor of mating success in many species (Eberhard, 1979; 
Brock et. al., 1982; Emlen, 1996). The aspect of dimorphism varies across taxa with females generally being larger than males in insects (Andersson, 1994; Fairbairn et al., 2007). The Turkish endemic species, Dorcadion micans J. Thomson, 1867 was described by J. Thomson (1867) from Anatolia. The fore tarsus and gonads are often used to determine the sex of this species. Although there is a noticeable dimorphism in total size between the sexes in Dorcadion species, there is no study showing this dimorphism in different body parts. In addition, there is no study on how much this size variation reflects on the shape differences.

Morphometrics is a great technique that extracts the shape information of the organism being studied and combine them with multivariate statistics. It allows to researchers to solve complex problems in many fields of biology (Zelditch et al., 2012). This used technique in many studies in recent years, is extremely helpful to determine both the size and shape differences between the sexes of the Coleoptera species (Benítez, 2013; Benítez et. al., 2013; Lemic et al., 2014; Lemic et al., 2016; Mikac et al., 2016; Nair et al., 2019; Vesovic et al., 2019). Geometric morphometrics was applied to analyze two sympatric species Colophon haughtoni Barnard, 1929, and Colophon kawaii Mizukami, 1997, to analyze intersexual and interspecific variation of size and shape (Eldred, et., al. 2016). The differences in size and shape of the body structures thought to be responsible for sexual selection in Japanese beetles were also studied by this method (Kelly, 2020). In the literature, there is also a study to identify the shape influence of size in Cicindelidae trifasciata Fabricius, 1781, on sexual and non-sexual characteristics (Donoso et. al., 2020). However, no study has attempted to identify the sexual size and shape dimorphism on Dorcadion micans using geometric morphometrics. The aim of this study is to evaluate shape and size differentiation of pronotum between males and females and to identify shape influence of size in Dorcadion micans.

\section{MATERIAL AND METHOD}

Samples of Dorcadion micans were collected from the locality in Beynam village, Bala/Ankara 3941'34.2"N 3256'13.3"E, on March-April 2018. Sexes of samples were distinguished by the shape and size of the fore tarsus and confirm by using gonads. A total of 77 specimens (32 females and 45 males) were used in this study. Pronotum of the beetles was positioned and photographed by a camera attached to Leica EZ4HD microscope. To capture the shape of pronotum, we selected configurations of 10 landmarks. (Figure 1). The landmarks were digitized by using TpsDig2 software (Rohlf, 2013) and their detailed definitions are listed in (Figure 1).

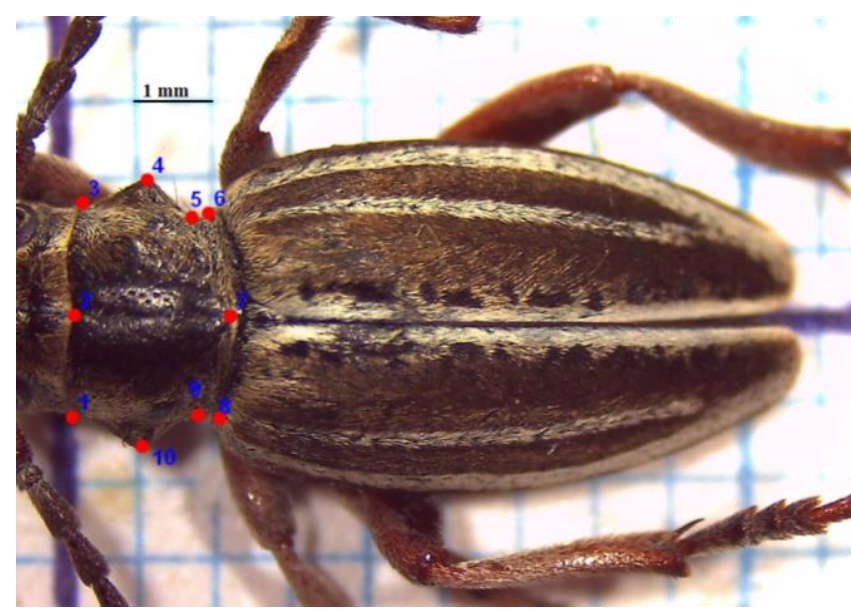

Figure 1. Selected landmarks on Dorcadion micans male, representing the dorsal side of the pronotum: 1) Anterior margin left edge; 2) middle of anterior margin; 3) anterior margin right edge; 4) right spine apex; 5) right protuberance posterior limit; 6) posterior right edge; 7) middle of posterior margin; 8) posterior margin left edge; 9) left protuberance posterior limit; and 10) left spine apex.

Statistical Analysis: The centroid size (square root of the sum of the square distances between each landmark and the centroid) was computed to compare pronotum size between sexes. (Bookstein, 1986). The software package MorphoJ (Klingenberg, 2011) was used to perform all statistical analyses in this study, except the independent samples t-test which was performed using the IBM SPSS 25. A generalized procrustes analysis (GPA) has been developed to superimposition of landmark configurations and to eliminate the effects of translation, rotation, and scale (Rohlf, 1999). Principal component analysis (PCA) was performed to determine morphometric variation, then discriminant function analysis (DFA) with cross validation was performed to determine the degree of morphological distinction between sexes. Finally, multivariate regression analysis was performed to determine the effect of size onto shape.

\section{RESULTS}

Size Variation: Centroid size variances were found to be equal between the sexes by Levene's test $(\mathrm{F}=2.486, \mathrm{p}=0.119)$. The independent samples $\mathrm{t}$-test showed that the CS mean of males is significantly different from that of the females. $(\mathrm{t}=6.386, \mathrm{df}=75, \mathrm{p}=0.000)$. Figure 2 shows box-plot of CS between sexes. Further, females appear to be larger than males with respect to CS of pronotum.

Shape Variation: PCA showed that $70.1 \%$ of the total variation of pronotum shape was explained by the first two principal components. (PC1 explains $64.1 \%$ and PC2, 
6.8\%). (Fig. 3). The analyzed sexes for pronotum shape were clearly separated along the first component axis.

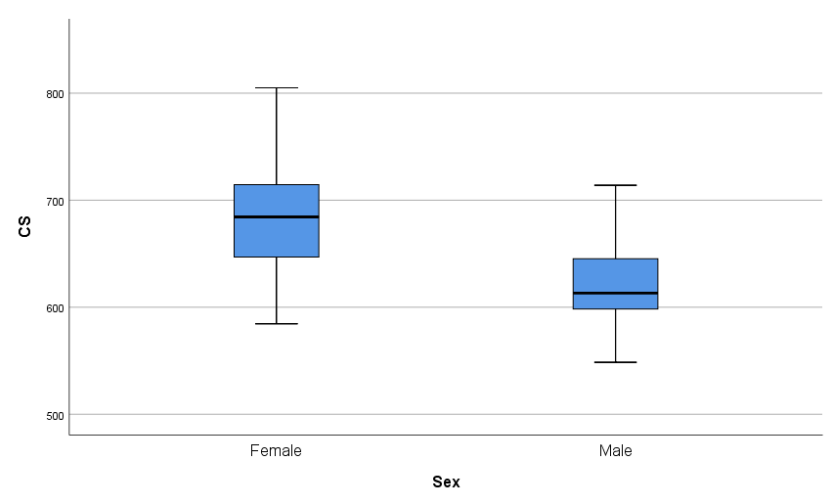

Figure 2. Box-plot of centroid size for pronotum for males and females of Dorcadion micans.

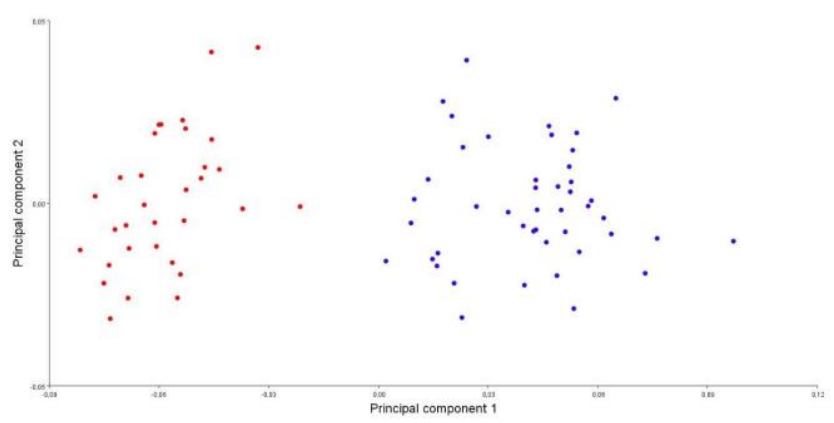

Figure 3. Shape differences between sexes, female (red) and male (blue).

DFA was performed to determine the degree of morphological separation between the sexes. The DFA with cross validation evidenced that $100 \%$ of female group and $100 \%$ of male group were correctly classified (Figure. 4). DFA showed that there is a statistically significant difference between means of procrustes distance of sexes $(\mathrm{P}<0.0001)$. Also, the results of DFA show that all the landmarks with the greatest variation indicating that females have a wider and shorter pronotum than males. This is also related to elongated and sharpened from both anterior and posterior parts of the pronotum shape in male (Figure 4).

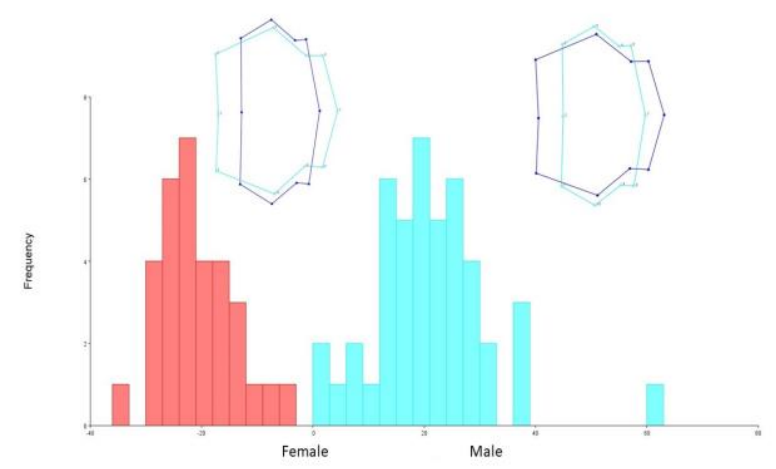

Figure 4. Cross validation scores of shape variables of pronotum. Wire-frame graphs were shown for female and male respectively at the top of left and right of each figure. The extreme changes of shape in positive and negative direction were shown by the violet lines and mean shape of pronotum was shown by blue lines. The scale for figure is (-20 to 20).

Although multivariate regression of shape on centroid size was statistically significant that explained only 2.94 percent of the total variation in shape of pronotum $(2.94 \%, \mathrm{P}=0.0151)$. On the other words, pronotum shape difference is not related the size of the pronotum.

Although there many studies have found significant differences in pronotum shape in Coleoptera (Pizzo et al., 2006; Ober \& Connolly, 2015; Eldred et al., 2016; Li et al., 2016), geometric morphometrics was applied here for sexual dimorphism to Dorcadion micans for the first time. Vesovic et.al. 2019 investigated morphometric variation in size and shape of the head, pronotum, and abdomen between the taxa and sexes of two ground beetles and sexual shape dimorphism was found for all three body units in the taxa. Geometric morphometrics also revealed significant size and shape differences in the head, pronotum and elytron of Colophon and female Colophon kawaii were significantly larger than males for all structures (Eldred et. al., 2016). Our results have shown that females have a larger pronotum size than males, consistent with the literature (Dascălu \& Fusu, 2012). Sexual size and shape dimorphism are also evident in pronotum of Dorcadion micans. Multivariate regression of shape on size results indicated that size has negligible influence on the differentiation in pronotum shape among sexes. Thus, it can be said that the pronotum shape changes between the sexes are independent of pronotum size.

\section{CONCLUSION}

According to the results, the size and shape of the pronotum is an important morphological feature to distinguish the different sexes of Dorcadion. Geometric morphometrics is a powerful approach to analyze the sexual size and shape dimorphism in Dorcadion micans. More studies are needed to understand what causes the sexual shape dimorphism in beetles.

\section{REFERENCES}

Andersson, M. (1994). Sexual selection. Princeton, Princeton University Press, USA, 247-297p.

Baur, B., Zschokke, S., Coray, A., Schläpfer, M. \& Erhardt, A. (2002). Habitat characteristics of the endangered flightless beetle Dorcadion fuliginator (Coleoptera: Cerambycidae): implications for conservation. Biological Conservation, 105, 133-142. 
Baur, B., Coray, A., Minoretti, N. \& Zschokke, S. (2005). Dispersal of the endangered flightless beetle Dorcadion fuliginator (Coleoptera: Cerambycidae) in spatially realistic landscapes. Biological Conservation, 4, 9-61.

Benítez, H.A. (2013). Sexual dimorphism using geometric morphometric approach. In: Moriyama H (Ed.) Sexual Dimorphism. IntechOpen, London, 35$50 \mathrm{p}$.

Benítez, H.A., Sanzana, M.J., Jerez, V., Parra, L.E., Hernandez, C.E. \& Canales-Aguirre, C.B. (2013). Sexual shape and size dimorphism in carabid beetles of the genus Ceroglossus: is geometric body size similar between sexes due to sex ratio? Zoological Science, 30, 289-295.

Bookstein, F.L. (1986). Size and shape spaces for landmark data in two dimensions. Statistical Science, 1(2), 181-222.

Brock, T.H., Guinness, F.E. \& Albon, S.D. (1982). Red deer: behavior and ecology of two sexes. University of Chicago press, USA, 1-40p.

Dascălu, M. \& Fusu, L. (2012). Dorcadion axillare Küster, 1847 (Coleoptera: Cerambycidae): distribution, morphometrics, karyotype and description of a new subspecies from Romania. Zootaxa, 3322(1), 35-48. DOI: 10.11646/zootaxa.3322.1.2

Doğan Sarıkaya, A., Okutaner, A.Y. \& Sarıkaya, Ö. (2019). Geometric morphometric analysis of pronotum shape in two isolated populations of Dorcadion anatolicum Pic, 1900 (Coleoptera: Cerambycidae) in Turkey. Turkish Journal of Entomology, 43(3), 263-270. DOI: 10.16970/entoted.525860

Donoso, S.E., Angulo-Bedoya, M., Lemic, D. \& Benítez, H.A. (2020). Assessing the influence of allometry on sexual and non-sexual traits: An example in Cicindelidia trifasciata (Coleoptera: Cicindelinae) using geometric morphometrics. Zoologischer Anzeiger, 287, 61-66.

Eberhard, M.J. (1979). Sexual selection, social competition, and evolution. Proceedings of the American Philosophical Society, 123, 222-234.

Eldred, T., Meloro, C., Scholtz, C. \& Murphy, D. (2016). Does size matter for horny beetles? A geometric morphometric analysis of interspecific and intersexual size and shape variation in Colophon haughtoni Barnard, 1929, and C. kawaii Mizukami, 1997 (Coleoptera: Lucanidae). Organism Diversity Evolution, 16, 821-833.

Emlen, D.J. (1996). Artificial selection on horn lengthbody size allometry in the horned beetle Onthophagus acuminatus (Coleoptera: Scarabaeidae). Evolution, 50, 1219-1230.

Fairbairn, D.J. (2013). Odd Couples: Extraordinary Differences between the Sexes in the Animal Kingdom. Princeton University Press, USA, 1-9p.

Kelly, C.D. (2020). Sexual selection on size and shape in Japanese beetles (Popillia japonica). Behavioral Ecology, 31(4), 1073-1083.
Klingenberg, C.P. (2011). MorphoJ: an integrated software package for geometric morphometrics. Molecular Ecology Resources, 11(2), 353-357.

Lemic, D., Benítez, H.A. \& Bazok, R. (2014). Intercontinental effect on sexual shape dimorphism and allometric relationships in the beetle pest Diabrotica virgifera virgifera LeConte (Coleoptera: Chrysomelidae). Zool. Anz. J. Comp. Zool., 253(3), 203-206.

Lemic, D., Benítez, H.A., Püschel, T.A., Gasparic, H.V., Satvar, M. \& Bazok, R. (2016). Ecological morphology of the sugar beet weevil Croatian populations: Evaluating the role of environmental conditions on body shape. Zool. Anz. J. Comp.Zool, 260, 25-32.

Li, S., Ricchiardi, E., Bai, E.M. \& Yang, X. (2016). A taxonomy review of Oreoderus Burmeister, 1842 from China with a geometric morphometric evaluation (Coleoptera: Scarabaeidae). Zookeys, 552, 67-89. DOI: 10.3897/zookeys.552.6096

Nair, P., Hunter, A.H., Worsham, M.L., Stehle, M., Gibson, J.R. \& Nowlin, W.H. (2019). Sexual dimorphism in three species of Heterelmis Sharp (Coleoptera: Elmidae). Coleopt. Bull, 73, 10751083.

Ober, K.A. \& Connolly, T.C. (2015). Geometric morphometric and phylogenetic analyses of Arizona Sky Island populations of Scaphinotus petersi Roeschke (Coleoptera: Carabidae). Zoological Journal of the Linnean Society, 175, 107-118.

Pizzo, A., Mercurio, D., Palestrini, C., Roggero, A. \& Rolando, A. (2006). Male differentiation patterns in two polyphenic sister species of the genus Onthophagus Latreille, 1802 (Coleoptera: Scarabaeidae): a geometric morphometric approach. Journal of Zoological Systematics and Evolutionary Research, 44(1), 54-62.

Rohlf, F.J. (1999). Shape statistics: Procrustes superimpositions and tangent spaces. Journal of Classification, 16, 197- 223.

Rohlf, F.J. (2013). tpsDig, 2.17 (Web page: http://life.bio.sunysb.edu/morph) (Date accessed:11.05.2020).

Vesovic, N., Ivanovic, A. \& Curcic, S. (2019). Sexual size and shape dimorphism in two ground beetle taxa, Carabus (Procrustes) coriaceus cerisyi and C.(Morphocarabus) kollari praecellens (Coleoptera: Carabidae)-A geometric morphometric approach. Arthropod Structure \& Development, 49, 1-9.

Zelditch, M., Swiderski, D., Sheets, D. \& Fink, W. (2004). Geometric Morphometrics for Biologists: A Primer. Elsevier, London, UK, 1-70p. 